Kavinda, H. and Jayalath, C., 2019. Deriving a baseline score for selecting adaptive reusable projects: A quantitative approach. In: Sandanayake, Y.G., Gunatilake, S. and Waidyasekara, A. (eds). Proceedings of the $8^{\text {th }}$ World Construction Symposium, Colombo, Sri Lanka, 8-10 November 2019, pp. 248-257. DOI: doi.org/10.31705/WCS.2019.25. Available at: https://2019.ciobwcs.com/papers

\title{
DERIVING A BASELINE SCORE FOR SELECTING ADAPTIVE REUSABLE PROJECTS: A QUANTITATIVE APPROACH
}

\author{
Himesh Kavinda ${ }^{1}$ and Chandana Jayalath ${ }^{2}$
}

\begin{abstract}
Building Adaptive Reuse (BAR) has been recognized to be a viable option to deal with old building stock in spite of the trivial decision of either demolish or reuse. An objective scale to gauge the accuracy of this choice is however non-existent even there is a potential to do so. Hence, the aim of this research is to ease out this decision by developing a rational framework. A comprehensive literature survey, expert's interview and questionnaire survey was carried out. 35 experienced industry personnel participated in the questionnaire survey. The topics entailed were their exposure to BAR projects in Sri Lanka, BAR potential and drivers and barriers affecting BAR decision. Expert opinion was taken to verify the findings. In order to understand the importance level of each of the recognized factors, the Relative Important Index (RII) technique was used as the primary data analysis method. Analytical Hierarchical Process that involves pair-wise comparison, normalised comparison and consistency calculations was used to augment a baseline score in order to make the BAR decision rational. It was found that structural integrity is the highest priority acquiring $12.8 \%$ in the total factor score out of 36 globally important indices. The Overall Global Importance score has been considered in this decision making model against 5 successive adaptive reuse projects in Sri Lanka. A pass mark of 60 has to be the minimum threshold to proceed with adaptive reuse. The outcome offers a national benchmark.
\end{abstract}

Keywords: Analytical Hierarchical Process; Building Adaptive Reuse; Relative Importance Index.

\section{INTRODUCTION}

In the long run, buildings become obsolete or redundant. Continuous maintenance and restoration are needed in the building usage even if their life span extends up to decades and centuries (Langston andShen 2007). With this concern, a trend is to explore the possibility of reuse of old buildings before they fall into disrepair (Langston et al. 2008). The Department of Environmental and Heritage (DEH 2004) defines Building Adaptive Reuse (BAR) as "a process that changes a disused or in effective item into a new item that can be used for a different purpose". The benefit is that it gives neglected, out-dated buildings a liveliness that makes them once again attractive and useful (Campbell 1996). Almost all the historic cities now have realized that adaptive reuse of historic buildings marks a vital part of building renovation (Ball 2002). The processes of BAR is heavily contributed towards environmental sustainability through the mitigation of $\mathrm{CO}_{2}$

\footnotetext{
${ }^{1}$ Prime Land Residencies (Pvt) Ltd, Sri Lanka, kavinda.himesh@gmail.com

${ }^{2}$ Department of Quantity Surveying, University of Vocational Technology, Sri Lanka, chandanaj@univotec.ac.lk
} 
emissions (Bullen 2007). It reduces huge amounts of non-digested wastage generated through the demolition of old buildings. Adaptive reuse postures quite challenging for designers as the function changes of the buildings warrants the fulfilment of new regulatory conditions (Langston and Shen 2007). A successful adaptation is the one that respects the prevailing building and its historic background (DEH 2004). In Sri Lanka, a noticeable amount of buildings are located in Colombo, Galle Fort, Kandy as well as Jaffna and it could there be inferred that Sri Lanka has the potential of adopting BAR solutions. This arises the quest of rationality behind selection of projects for adaptive building reuse.

The aim of this research is to derive a decision making support model that enhances rationality of BAR decision. The objectives are to diagnose the factors that affect the decision making of building adaptive reuse, prioritize the most critical factors involved, develop a hierarchical order for identified critical factors that influence adaptation and augment a baseline score to make the BAR decisions, that are cogent and sensible.

\section{RESEARCH METHODOLOGY}

The process of decision making is dynamic so that an interpretative research would be ideal (Bullen and Love 2011; Loosemore 1999). A comprehensive literature survey was carried out using textbooks and research papers. 35 experienced industrial experts who had at least in a single BAR experience participated in the questionnaire survey. The topics entailed were the BAR potential, benefits, driving factors, the barriers affecting BAR decision. Expert opinion was taken to verify the findings. The Relative Important Index (RII) technique was used to obtain a ranking relative to the importance of such factors. RII was calculated using formula (01).

$$
R I I=\frac{\Sigma W \times 100}{A \times N}
$$

Where, $\mathrm{W}=$ weightage given to each factor by respondents, $\mathrm{A}=$ the highest weighting and $\mathrm{N}=$ total Number in the Responses.

The next step is the Analytic Hierarchy Process (AHP) which is a multi-criteria analysis on complex human judgments instead of analysis of mere information (Saaty 1990). This involves Pair-wise Comparison, Normalise the Comparison (deriving priority vectors) and Consistency Calculation (Ehrhardt and Tullar 2008). The decision maker expresses his preference between each pair of elements verbally according to a predefined numerical code based on its level of importance (Bayazit 2005). Accordingly, the numerical values from 1 to 9 were used to scale the responses. The ratio scales are derived from the principal Eigen vectors and the consistency index is derived from the principal Eigen value.

\section{ORIGINALITY AND IMPLICATIONS}

While the advantages of BAR have been generally embraced hither and thither, there is no consistency among the building owners to legitimize and assess their opinions as to its worth to reuse or demolish the existing assets (Bullen and Love 2011). On the other hand, BAR process is found to have been not that widespread in Sri Lanka. There is neither BAR base nor a BAR model. The focus of this study is to establish a rational approach to make this choice. 


\section{LITERATURE REVIEW}

Building obsolescence arises when there is an imbalance between the rate of change in market stresses and the rate at which the building stock is able to vary according to those changes (Williams 1986). According to Williams (1986), there are six types of building obsolescence; Physical obsolescence: relates to the condition of the building fabrics; Statutory obsolescence: occurs due to financial or technical difficulties arising from statutory requirements focussed on buildings; Economic obsolescence: relates to the building type demand and focus indirectly on the goods and services produced at the premises; Functional obsolescence: relates to the spatial arrangements of the building and its location site; Locational obsolescence: operational advantages related to the building location which is dependent on the market variations; Community obsolescence: local conflicts of interest as a result of the purpose and use of a building. Various forms of obsolescence are relative (Williams 1986). The main reason for this is, even if a building is outmoded in the context of a particular set of user requirements, it can still be renovated and used for alternative uses which can yield a high level of utility.

According to Langston and Shen (2007), physical factors can be identified and evaluated by examining the policy of maintenance and performance of a given building. Economic factors are mainly evaluated by the locality of the building. If the building is located in a business hub the economic value of the building is very high. The factors related to technology can be appraised with the building's energy consumption in operational activities (Conejos at el. 2014). Functional factors are assessed through the flexibility to change embedded in the design of the old building stock (Ellison et al. 2007). Social factors are often combined with the building function and the market place (Bullen 2007). Regulatory factors need to be evaluated in order to check whether the old building can meet the new existing building standards (Wilkinson and James 2009). Environmental factors can be assessed through the quality of the original design of the old building.

\section{DATA ANALYSIS}

Several factors impinge upon the BAR process; environmental, regulatory, social, technological, functional, economical and physical. Experts too held the same view. The sub factors which were identified through expert's interviews are given bold and italicized at last in each category for easy identification. In tracing out the existing level of involvement in the BAR practice, the questionnaire participants were requested to assign the level of importance.

The Relative Importance Indices (RII) of each sub factor was calculated to rank the most valuable factors (Table 1). The factors which were gained the RII value less than 0.6 were disregarded as they are not that significant for the BAR process (Holt 2004). The factors which the RII values over and above 0.6 are transferred for further analysis.

Table 1: Relative importance indices of factors

\begin{tabular}{cllr}
\hline Main Factors & Rank & \multicolumn{1}{c}{ Sub Factors } & RII \\
\hline Physical Factors & 1 & Material Durability & 0.967 \\
& 2 & Structural Integrity & 0.883 \\
& 3 & Foundation & 0.817 \\
& 4 & Maintainability & 0.783 \\
& 5 & Workmanship & 0.767 \\
\hline
\end{tabular}




\begin{tabular}{|c|c|c|c|}
\hline Main Factors & Rank & Sub Factors & RII \\
\hline & 6 & Design Complexity & 0.683 \\
\hline & 7 & Prevailing Climate & 0.583 \\
\hline \multirow[t]{6}{*}{ Economic Factor } & 1 & Cost of Construction & 0.933 \\
\hline & 2 & Market Proximity & 0.917 \\
\hline & 3 & Touristic Attraction & 0.876 \\
\hline & 4 & Transport Infrastructure & 0.850 \\
\hline & 5 & Plot Size & 0.783 \\
\hline & 6 & Planning Constrain & 0.767 \\
\hline \multirow[t]{8}{*}{ Functional Factor } & 1 & Flexibility & 0.967 \\
\hline & 2 & Structural Grid & 0.917 \\
\hline & 3 & Service Duct and Corridor & 0.883 \\
\hline & 4 & Convertibility & 0.817 \\
\hline & 5 & Disassembly & 0.783 \\
\hline & 6 & Spatial Flow and Atria & 0.717 \\
\hline & 7 & Compartmentalization & 0.550 \\
\hline & 8 & Tenancies & 0.500 \\
\hline \multirow{6}{*}{$\begin{array}{l}\text { Technological } \\
\text { Factors }\end{array}$} & 1 & Orientation & 0.917 \\
\hline & 2 & Complexity & 0.900 \\
\hline & 3 & Glazing & 0.783 \\
\hline & 4 & Insulation and Shading & 0.767 \\
\hline & 5 & Natural Lighting and Ventilation & 0.750 \\
\hline & 6 & Building Management System & $\mathbf{0 . 5 0 0}$ \\
\hline \multirow[t]{8}{*}{ Social Factor } & 1 & History & 0.850 \\
\hline & 2 & Urban Master Plan & 0.833 \\
\hline & 3 & Image & 0.817 \\
\hline & 4 & Passion and Identity & 0.812 \\
\hline & 5 & Landscape & 0.800 \\
\hline & 6 & Aesthetic & 0.783 \\
\hline & 7 & Adjacent Building & 0.550 \\
\hline & 8 & Sense of Belonging & 0.526 \\
\hline \multirow{6}{*}{$\begin{array}{l}\text { Regulatory } \\
\text { Factor }\end{array}$} & 1 & Indoor Environmental Quality & 0.817 \\
\hline & 2 & Occupational Health and Safety & 0.800 \\
\hline & 3 & Standard of Finishes & 0.783 \\
\hline & 4 & Fire Protection & 0.767 \\
\hline & 5 & Disability Access & 0.683 \\
\hline & 6 & Security & 0.533 \\
\hline \multirow{8}{*}{$\begin{array}{l}\text { Environmental } \\
\text { Factor }\end{array}$} & 1 & Raw Material Consumption & 0.900 \\
\hline & 2 & Pollution and Biodiversity & 0.817 \\
\hline & 3 & Conservation & 0.800 \\
\hline & 4 & Waste Creation & 0.717 \\
\hline & 5 & Cleanliness/ Good Appearance & 0.705 \\
\hline & 6 & Acoustic & 0.683 \\
\hline & 7 & Ecological Footprint & 0.700 \\
\hline & 8 & Community Interest & 0.567 \\
\hline
\end{tabular}




\subsection{PAIRWISE COMPARISON}

A total number of 21 comparisons were considered. The average of level of importance obtained through 35 respondents is given in Table 2 in bold. Basically, each cell value of the comparison matrix enhances the numerical representation of the importance relationship between two main factors.

Table 2: Pairwise comparison matrix for main factors

\begin{tabular}{lccccccc}
\hline \multicolumn{1}{c}{ Factors } & Physical & Economic & Functional & Technological & Social & Regulatory & Envir' \\
\hline Physical & 1.000 & $\mathbf{1 . 5 4 8}$ & $\mathbf{1 . 4 7 4}$ & $\mathbf{2 . 3 5 9}$ & $\mathbf{2 . 0 1 1}$ & $\mathbf{2 . 7 6 9}$ & $\mathbf{2 . 8 6 7}$ \\
Economic & 0.646 & 1.000 & $\mathbf{0 . 6 4 1}$ & $\mathbf{2 . 1 1 5}$ & $\mathbf{1 . 5 7 1}$ & $\mathbf{2 . 3 5 4}$ & $\mathbf{1 . 3 8 1}$ \\
Functional & 0.678 & 1.560 & 1.000 & $\mathbf{2 . 6 8 4}$ & $\mathbf{2 . 5 9 2}$ & $\mathbf{3 . 0 0 4}$ & $\mathbf{2 . 2 2 6}$ \\
Technological & 0.424 & 0.473 & 0.373 & 1.000 & $\mathbf{0 . 7 2 4}$ & $\mathbf{1 . 5 9 7}$ & $\mathbf{0 . 4 8 8}$ \\
Social & 0.497 & 0.637 & 0.386 & 1.382 & 1.000 & $\mathbf{1 . 8 5 4}$ & $\mathbf{0 . 5 6 1}$ \\
Regulatory & 0.361 & 0.425 & 0.333 & 0.626 & 0.539 & 1.000 & $\mathbf{0 . 4 5 6}$ \\
Environmental & 0.349 & 0.724 & 0.446 & 2.048 & 1.783 & 2.192 & 1.000 \\
Total & 3.956 & 6.366 & 4.656 & 12.214 & 10.20 & 14.700 & 8.979 \\
\hline
\end{tabular}

\subsection{NORMALIZED COMPARISON}

Data summarized in the pairwise comparison matrix were then transferred to normalize by dividing each comparison matrix cell entry by the sum of the respective column. Moving forward each of the row total were then calculated to derive the average of each row with the mean of the "Importance Index" of each main factor. These main factors' overall importance can also be named as main factor "Performance Score" or "Relative Weightings" (Saaty, 1990). To fill the lower triangular matrix, the reciprocal values of the upper diagonal were used (refer Table 3).

Table 3: Normalized weighting matrix for main factors

\begin{tabular}{|c|c|c|c|c|c|c|c|c|c|}
\hline \multicolumn{8}{|c|}{ Normalized Weightings Matrix: Main Factors } & \multirow{2}{*}{ Sum } & \multirow{2}{*}{$\begin{array}{l}\text { Importance } \\
\text { Index }\end{array}$} \\
\hline Factor & Physical & Economic & Functional & Technological & I Social & Regulatory & Envir' & & \\
\hline Physical & 0.253 & 0.243 & 0.317 & 0.193 & 0.197 & 0.187 & 0.319 & 1.709 & 0.244 \\
\hline Economical & 0.163 & 0.157 & 0.138 & 0.173 & 0.154 & 0.159 & 0.154 & 1.098 & 0.157 \\
\hline Functional & 0.172 & 0.245 & 0.215 & 0.220 & 0.254 & 0.203 & 0.248 & 1.556 & 0.222 \\
\hline Technological & 0.107 & 0.074 & 0.080 & 0.082 & 0.071 & 0.108 & 0.054 & 0.577 & 0.082 \\
\hline Social & 0.126 & 0.100 & 0.083 & 0.113 & 0.098 & 0.126 & 0.062 & 0.708 & 0.101 \\
\hline Regulatory & 0.091 & 0.067 & 0.072 & 0.051 & 0.053 & 0.068 & 0.051 & 0.452 & 0.065 \\
\hline \multirow[t]{2}{*}{ Environmental } & 0.088 & 0.114 & 0.096 & 0.168 & 0.174 & 0.148 & 0.111 & 0.900 & 0.129 \\
\hline & & & & & & & & 7.000 & 1.000 \\
\hline
\end{tabular}

\subsection{CONSISTENCY CALCUlation}

Being the final step in the AHP process, it is required to validate the data collected through the questionnaires and measure the consistency of judgments made by the respondents. The results are tabulated in Table 4. The Consistency Index as deviation or degree of consistency was calculated using formula (02). 


$$
C I=\frac{\lambda_{\max }-n}{n-1}
$$

Table 4: Consistency calculation matrix for main factors

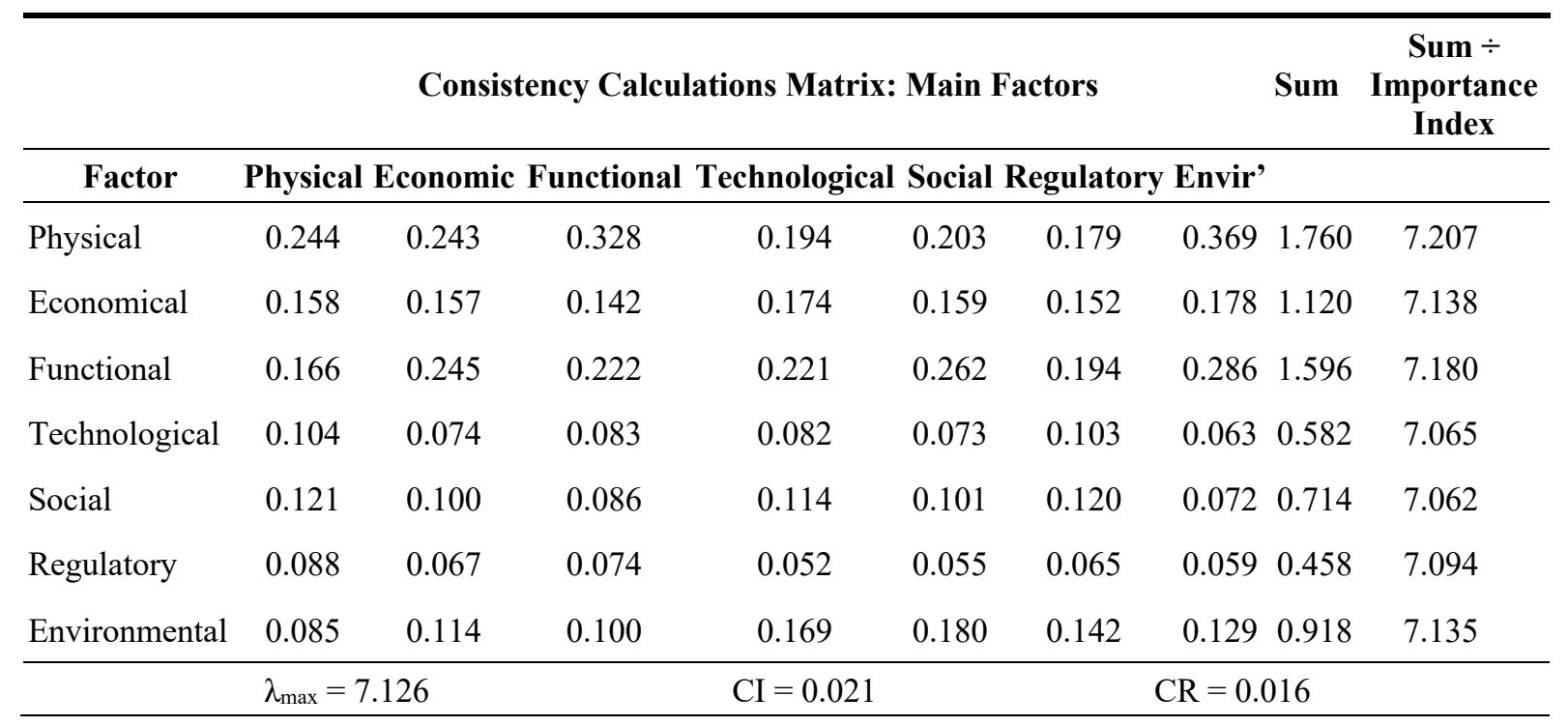

Considering the space constraints in this research paper, AHP Approach for Individual Sub-Factors and their net resultant impact is not given.

\subsection{Assigning Global Priorities for Sub Factors}

The Overall Factor Score was calculated by multiplying each sub-factor local importance index from the importance index of their main factor category (refer Table 5). The global factor scores are listed together with their global ranking as each and every sub-factors earned.

Table 5: Global importance indices for sub-factors

\begin{tabular}{|c|c|c|c|c|c|}
\hline Main F & ctor & & Sub Factors & & \\
\hline Factor name & $\begin{array}{l}\text { Importance } \\
\text { Index }\end{array}$ & Sub-Factor name & $\begin{array}{c}\text { Local } \\
\text { Importance } \\
\text { Index } \\
\end{array}$ & $\begin{array}{c}\text { Global } \\
\text { Importance } \\
\text { Index }\end{array}$ & $\begin{array}{c}\text { Global } \\
\text { Rank }\end{array}$ \\
\hline \multirow{6}{*}{ Physical Factor } & \multirow{6}{*}{0.244} & Material Durability & 0.229 & 0.056 & 3 \\
\hline & & Structural Integrity & 0.324 & 0.079 & 1 \\
\hline & & Foundation & 0.167 & 0.041 & 5 \\
\hline & & Maintainability & 0.123 & 0.030 & 11 \\
\hline & & Workmanship & 0.073 & 0.018 & 26 \\
\hline & & Design Complexity & 0.084 & 0.020 & 19 \\
\hline \multirow{5}{*}{ Economic Factor } & \multirow{5}{*}{0.157} & $\begin{array}{l}\text { Cost of Constructing } \\
\text { Building }\end{array}$ & 0.226 & 0.035 & 8 \\
\hline & & Market Proximity & 0.185 & 0.029 & 12 \\
\hline & & $\begin{array}{l}\text { Touristic Attraction \& } \\
\text { Value }\end{array}$ & 0.289 & 0.045 & 4 \\
\hline & & Transport Infrastructure & 0.082 & 0.013 & 29 \\
\hline & & Plot Size & 0.149 & 0.023 & 16 \\
\hline
\end{tabular}




\begin{tabular}{|c|c|c|c|c|c|}
\hline \multicolumn{2}{|c|}{ Main Factor } & \multicolumn{4}{|c|}{ Sub Factors } \\
\hline Factor name & $\begin{array}{l}\text { Importance } \\
\text { Index }\end{array}$ & Sub-Factor name & $\begin{array}{c}\text { Local } \\
\text { Importance } \\
\text { Index }\end{array}$ & $\begin{array}{c}\text { Global } \\
\text { Importance } \\
\text { Index }\end{array}$ & $\begin{array}{c}\text { Global } \\
\text { Rank }\end{array}$ \\
\hline & & Planning Constrain & 0.068 & 0.011 & 33 \\
\hline \multirow{6}{*}{$\begin{array}{l}\text { Functional } \\
\text { Factor }\end{array}$} & \multirow{6}{*}{0.222} & Flexibility & 0.332 & 0.074 & 2 \\
\hline & & Structural Grid & 0.181 & 0.040 & 7 \\
\hline & & $\begin{array}{l}\text { Service Duct and } \\
\text { Corridor }\end{array}$ & 0.151 & 0.034 & 9 \\
\hline & & Convertibility & 0.100 & 0.022 & 17 \\
\hline & & Disassembly & 0.089 & 0.020 & 21 \\
\hline & & Spatial Flow \& Atria & 0.148 & 0.033 & 10 \\
\hline \multirow{5}{*}{$\begin{array}{l}\text { Technological } \\
\text { Factor }\end{array}$} & \multirow{5}{*}{0.082} & Orientation & 0.322 & 0.027 & 15 \\
\hline & & Complexity & 0.218 & 0.018 & 25 \\
\hline & & Glazing & 0.111 & 0.009 & 37 \\
\hline & & Insulation and Shading & 0.229 & 0.019 & 22 \\
\hline & & $\begin{array}{l}\text { Natural Lighting \& } \\
\text { Ventilation }\end{array}$ & 0.120 & 0.010 & 36 \\
\hline \multirow{6}{*}{ Social Factor } & \multirow{6}{*}{0.101} & History & 0.277 & 0.028 & 13 \\
\hline & & Urban Master Plan & 0.205 & 0.021 & 18 \\
\hline & & Image & 0.157 & 0.016 & 28 \\
\hline & & Passion and Identity & 0.171 & 0.017 & 27 \\
\hline & & Landscape & 0.084 & 0.008 & 38 \\
\hline & & Aesthetic & 0.107 & 0.011 & 32 \\
\hline \multirow{5}{*}{$\begin{array}{l}\text { Regulatory } \\
\text { Factor }\end{array}$} & \multirow{5}{*}{0.065} & $\begin{array}{l}\text { Indoor Environmental } \\
\text { Quality }\end{array}$ & 0.286 & 0.018 & 24 \\
\hline & & $\begin{array}{l}\text { Occupational Health and } \\
\text { Safety }\end{array}$ & 0.310 & 0.020 & 20 \\
\hline & & Standard of Finishes & 0.165 & 0.011 & 34 \\
\hline & & Fire Protection & 0.129 & 0.008 & 39 \\
\hline & & Disability Access & 0.110 & 0.007 & 41 \\
\hline \multirow{7}{*}{$\begin{array}{l}\text { Environmental } \\
\text { Factor }\end{array}$} & \multirow{7}{*}{0.129} & $\begin{array}{l}\text { Raw Material } \\
\text { Consumption }\end{array}$ & 0.316 & 0.041 & 6 \\
\hline & & $\begin{array}{l}\text { Pollution and } \\
\text { Biodiversity }\end{array}$ & 0.215 & 0.028 & 14 \\
\hline & & Conservation & 0.145 & 0.019 & 23 \\
\hline & & Waste Creation & 0.080 & 0.010 & 35 \\
\hline & & $\begin{array}{l}\text { Cleanliness \& Good } \\
\text { Appearance }\end{array}$ & 0.095 & 0.012 & 30 \\
\hline & & Acoustic & 0.089 & 0.011 & 31 \\
\hline & & Ecological Footprint & 0.060 & 0.008 & 40 \\
\hline
\end{tabular}




\subsection{ASSIGNING BENCHMARK SCORE}

Five industrial experts were requested to score between 0-100 considering the use of each shortlisted critical factor. Average of each respondent's scores is summarized in Table 6. Accordingly, the minimum total score among these BAR projects was selected as the base line score of the developed model.

Table 6: Total factor score in BAR decision making model

\begin{tabular}{|c|c|c|c|c|c|c|c|c|c|c|c|c|}
\hline \multirow{2}{*}{$\begin{array}{c}\text { Global } \\
\text { Ranking } \\
\text { of the } \\
\text { Factor }\end{array}$} & \multirow{2}{*}{$\begin{array}{l}\text { Selection } \\
\text { Factors }\end{array}$} & \multirow{2}{*}{$\begin{array}{c}\text { Overall } \\
\text { Importance } \\
\text { Indices }\end{array}$} & \multicolumn{2}{|c|}{ Project A } & \multicolumn{2}{|c|}{ Project B } & \multicolumn{2}{|c|}{ Project C } & \multicolumn{2}{|c|}{ Project D } & \multicolumn{2}{|c|}{ Project E } \\
\hline & & & U.F. & Score & U.F. & Score & U.F. & Score & U.F. & Score & U.F. & Score \\
\hline 1 & $\begin{array}{l}\text { Structural } \\
\text { Integrity }\end{array}$ & 0.128 & 81.50 & 10.42 & 76.50 & 9.78 & 52.00 & 6.65 & 60.50 & 7.74 & 73.40 & 9.39 \\
\hline 2 & Flexibility & 0.119 & 72.00 & 8.58 & 67.40 & 8.03 & 66.00 & 7.86 & 55.70 & 6.63 & 81.50 & 9.71 \\
\hline 3 & $\begin{array}{l}\text { Material } \\
\text { Durability }\end{array}$ & 0.090 & 75.40 & 6.82 & 85.60 & 7.74 & 66.20 & 5.98 & 84.60 & 7.65 & 72.80 & 6.58 \\
\hline 4 & $\begin{array}{l}\text { Touristic } \\
\text { Attraction \& } \\
\text { Value }\end{array}$ & 0.073 & 84.60 & 6.20 & 91.50 & 6.71 & 77.70 & 5.70 & 66.50 & 4.88 & 99.00 & 7.26 \\
\hline 5 & Foundation & 0.066 & 77.70 & 5.13 & 95.30 & 6.29 & 70.80 & 4.67 & 36.80 & 2.43 & 91.70 & 6.05 \\
\hline 6 & $\begin{array}{l}\text { Raw Material } \\
\text { Consumption }\end{array}$ & 0.066 & 77.70 & 5.10 & 62.50 & 4.10 & 70.00 & 4.60 & 28.60 & 1.88 & 79.60 & 5.23 \\
\hline 7 & Structural Grid & 0.065 & 78.50 & 5.11 & 86.50 & 5.63 & 60.80 & 3.95 & 43.50 & 2.83 & 75.70 & 4.92 \\
\hline 8 & $\begin{array}{l}\text { Cost of } \\
\text { Constructing } \\
\text { Building }\end{array}$ & 0.057 & 32.50 & 1.86 & 65.20 & 3.73 & 58.50 & 3.35 & 55.80 & 3.19 & 77.60 & 4.44 \\
\hline 9 & $\begin{array}{l}\text { Service Duct \& } \\
\text { Corridor }\end{array}$ & 0.054 & 62.30 & 3.38 & 33.50 & 1.82 & 70.60 & 3.83 & 73.50 & 3.99 & 81.40 & 4.42 \\
\hline 10 & $\begin{array}{l}\text { Spatial Flow \& } \\
\text { Atria }\end{array}$ & 0.053 & 54.80 & 2.91 & 63.60 & 3.37 & 80.40 & 4.26 & 76.40 & 4.05 & 79.50 & 4.22 \\
\hline 11 & Maintainability & 0.048 & 63.50 & 3.07 & 71.50 & 3.46 & 84.60 & 4.09 & 67.60 & 3.27 & 75.40 & 3.64 \\
\hline 12 & $\begin{array}{l}\text { Market } \\
\text { Proximity }\end{array}$ & 0.047 & 66.40 & 3.11 & 84.60 & 3.97 & 87.60 & 4.11 & 58.90 & 2.76 & 89.50 & 4.20 \\
\hline 13 & History & 0.045 & 80.80 & 3.65 & 94.50 & 4.27 & 72.60 & 3.28 & 75.60 & 3.42 & 95.10 & 4.30 \\
\hline 14 & $\begin{array}{l}\text { Pollution and } \\
\text { Biodiversity }\end{array}$ & 0.045 & 64.60 & 2.89 & 77.50 & 3.47 & 74.50 & 3.33 & 69.60 & 3.11 & 70.90 & 3.17 \\
\hline 15 & Orientation & 0.043 & 68.10 & 2.92 & 83.70 & 3.59 & 71.20 & 3.05 & 58.80 & 2.52 & 72.70 & 3.12 \\
\hline & Total Score & 1.000 & 71 & .15 & 75. & & 68. & .72 & & .35 & 80 & .64 \\
\hline \multicolumn{11}{|c|}{ Base Line Score for Successive BAR Project Selection } & 60 & $\%$ \\
\hline
\end{tabular}

\section{FINDINGS AND CONCLUSIONS}

If the CR becomes less than 0.10, it means the used data were consistent (Saaty, 1990). As the CR value in the above matrix is 0.016 , it can be inferred that the data used for developing the "Importance Indices" of Main Factors are obtained through consistent judgments. Accordingly, the Importance Indices and their individual perceptions entail a higher level of validity. Among the sub-factors the highest level of overall importance was indicated by "Structural Integrity". The first 15 highest ranking sub-factors were 
taken to consider and locate the Overall Importance or the Global Importance score. This was implemented on 5 different BAR projects and revealed that $60 \%$ score is the minimum threshold in qualifying a successful adaptive reuse project.

\section{REFERENCES}

Ball, R.M., 2002. Re-use potential and vacant industrial premises: Revisiting the regeneration issue in Stoke-on-Trent, Journal of Property Research, 19(2), pp.93-110

Bayazit, O., 2005. Use of AHP in decision-making for flexible manufacturing systems, Journal of Manufacturing Technology Management, 16(7), pp.808-819.

Bullen, P.A., 2007. Adaptive reuse and sustainability of commercial buildings, Facilities, 25(1/2), pp.2031.

Bullen, P.A. and Love, P.E.D., 2009. Residential regeneration and adaptive reuse: Learning from the experiences of Los Angeles, Structural Survey, 27(5), pp.351-360.

Bullen, P.A. and Love, P.E.D., 2010. The rhetoric of adaptive reuse or reality of demolition: Views from the field, Cities, 27(4), pp.215-224.

Bullen, P.A. and Love, P.E.D., 2011. Factors influencing the adaptive re-use of buildings, Journal of Engineering, Design and Technology, 9(1), pp.32-46.

Bullen, P.A. and Love, P.E.D., 2011a. A new future for the past: A model for adaptive reuse decisionmaking, Built Environment Project and Asset Management, 1(1), pp.32- 44.

Bullen, P.A. and Love, P.E.D., 2011b. Adaptive reuse of heritage buildings, Structural Survey, 29(5), pp. 411-421.

Campbell, J., 1996. Is your building a candidate for adaptive reuse?, Journal of Property Management, 61(1), pp.26-29.

Cantell, S.F., 2005. The Adaptive reuse of historic industrial buildings: Regulation barriers, best practices and case studies. Available at: http://sig.urbanismosevilla.org/Sevilla.art/SevLab/r001US2_files/r001_US_1.pdf [Accessed on 14 August 2016].

Conejos, S., Langston, C. and Smith, J., 2014. Designing for better building adaptability: A comparison of adaptSTAR and ARP models, Habitat International, 41, pp.85-91.

Department of Environment and Heritage, 2004. Adaptive Reuse. Available at: https://www.environment.gov.au/system/files/resources/3845f27a-ad2c-4d40-8827$18 \mathrm{c} 643 \mathrm{c} 7 \mathrm{adcd} /$ files/adaptive-reuse.pdf [Accessed on 2 August 2016].

Douglas, J., 2006. Building Adaptation. $2^{\text {nd }}$ edn. Oxon: Spon Press.

Ehrhardt R., and Tuller, W.L., 2008. Rating Recruiting Sources at Simtec Instruments Corporation: Applying Multiple-criterion Decision Making in an HR Setting. Journal of Human Resources Education, 2(1), pp.1-11.

Holt, G., 2014. Asking questions, analysing answers: relative importance revisited. Construction Innovation, 14(1), pp. 2-16.

Langston, C., 2011. On Archetypes and Building Adaptive Reuse. Available at: http://www.prres.net/papers/langston_on_archetypes_and_building_adaptive_reuse.pdf [Accessed on 25 June 2016].

Langston, C. and Shen, L.Y., 2007. Application of the adaptive reuse potential model in Hong Kong: a case study of Lui Seng Chun. International Journal of Strategic Property Management, 11(4), pp.193-207.

Langston, C., Wong, F.K.W., Hui, E.C.M. and Shen, L.Y., 2008. Strategic assessment of building adaptive reuse opportunities in Hong Kong. Building and Environment, 43(10), pp.1709-1718.

Loosemore, M., 1999. A grounded theory of construction crisis management. Construction Management and Economics, 17(1), pp.9-19.

Saaty, T. L., 1990. How to Make a Decision: The Analytic Hierarchy Process. European Journal of Operational Research, 48(1), pp.9-26.

Thomsen, A.C.A. and Flier, K.V.D., 2011. Understanding obsolescence: a conceptual model for buildings. Building Research \& Information, 39(4), pp.352-362. 
Velthuis, KK. and Spennemann, DD.H.R., 2007. The future of defunct religious buildings: Dutch approaches to their Adaptive re-use, Cultural Trends, 16(1), pp.43-66.

Wilkinson, SS., Remøy, HH. and Langston, C., 2014. Sustainable building adaptation: Innovations in decision-making. United Kingdom: Wiley-Blackwell.

Wilkinson, S.J., James, K. and Reed, R., 2009. Using building adaptation to deliver sustainability in Australia. Structural survey, 27(1), pp.46-61.

Wong, J.K. and Li, H., 2008. Application of the analytic hierarchy process (AHP) in multi-criteria analysis of the selection of intelligent building systems. Building and Environment, 43(1), pp.108-125. 